\title{
Partial Purification and Characterization of Two Non K99 Mannose- resistant Haemagglutinins of Escherichia coli B41
}

\author{
By N. CHANTER \\ Agricultural Research Council, Institute for Research on Animal Diseases, Compton, Newbury, \\ Berkshire RG16 ONN, U.K.
}

(Received 13 April 1982; revised 11 June 1982)

\begin{abstract}
A K99- variant of Escherichia coli B41 was produced by growing the parent strain in the presence of antiserum to $E$. coli K12K99. Two mannose-resistant and eluting (MRE) haemagglutinins with molecular weights greater than $20 \times 10^{6}$ were extracted from the cell surface of the variant. One was an anionic antigen, partially purified by ammonium sulphate and isoelectric point precipitation, which adhered to calf intestinal brush borders; it was a protein composed of subunits with mol. wt 34000 . Electron microscopy showed that this material did not have a regular fimbrial appearance, but contained some fine fibrillar structures. A second MRE haemagglutinin which was also partially purified by ammonium sulphate precipitation, had a definite fimbrial structure, being a protein composed of two subunits of mol. wt 49500 and 48000 . This antigen was probably responsible for the fimbrial appearance of the K99- variant, but it was antigenically distinct from the anionic adhesin and did not adhere to calf intestinal brush borders.
\end{abstract}

\section{INTRODUCTION}

Adhesion to the surface of the small intestine, assisted by the fimbrial antigen K99 (Smith \& Lingood, 1972), may be the first step in the colonization process by some enterotoxigenic Escherichia coli in calves, lambs and piglets (Moon et al., 1977). Morris et al. (1980) described antibodies in antisera to all the $\mathrm{K} 99 \mathrm{E}$. coli strains tested which reacted with a cationic antigen of $E$. coli $\mathrm{B} 41$; this antigen was $\mathrm{K} 99$. Antibodies in antisera to some $\mathrm{K} 99 \mathrm{E}$. coli strains also reacted with an anionic antigen of $E$. coli $\mathrm{B} 41$. Antigen preparations that contained either, but not both antigens, caused MRE haemagglutination of horse and sheep erythrocytes. Only the preparation which contained the anionic antigen consistently inhibited adhesion of $E$. coli B41 to calf intestinal brush borders.

Chanter (1982) showed that a haemagglutinin of polypeptide subunits with mol, wt 19000 comprised the cationic antigen $\mathrm{K} 99$ and that the anionic antigen consisted of a haemagglutinin of polypeptide subunits with mol. wt 34000 .

Further characterization of the anionic adhesin in this laboratory has been hampered by purification procedures (ammonium sulphate and isoelectric point precipitation, ion exchange and gel filtration chromatography, preparative electrophoresis, immunoelectrophoresis, and haemadsorption) that resulted in preparations contaminated by K99. Methods which overcame these difficulties have been developed and these have enabled demonstration of a third MRE haemagglutinin on the $\mathrm{K} 99$ reference strain $E$. coli B41.

Abbreviations: IE, Immunoelectrophoresis; IRA, immunoradiometric assay; MRE, mannose-resistant and eluting haemagglutinin; PBS, phosphate-buffered saline. 


\section{METHODS}

Escherichia coli. Escherichia coli strains B41 (O101 : K99), B117 (O8:K85, K99), S13 (O8:K85, K99), a K12 and a K12 K99+ transconjugate of $E$. coli B41 were kindly supplied by Mr M. R. Burrows. Strains W1 (O149:K91, $\mathrm{K} 88 \mathrm{ac}$ ), M2225 (O9:K103, 987p) and K12 strains C600 and F711 were kindly supplied by Mr R. Sellwood. Unless otherwise stated, bacteria were grown at $37^{\circ} \mathrm{C}$ for $18 \mathrm{~h}$ on modified TGX agar (Burrows et al., 1976) containing $0 \cdot 1 \%(w / v)$ Lab Lemco (Oxoid).

Antisera. Antisera to bacteria were prepared in rabbits (Sojka, 1965) and, where necessary, absorbed with homologous bacteria grown at $18^{\circ} \mathrm{C}$. Bacteria grown at $18^{\circ} \mathrm{C}$ do not produce $\mathrm{K} 99$ or the anionic adhesin described by Morris et al. (1980). Antisera to the partially purified fractions of $E$. coli were prepared in rabbits using two subcutaneous inoculations, separated by 4 weeks, of $2 \mathrm{mg}$ material in $2 \mathrm{ml}$ Freund's incomplete adjuvant (Difco). Antisera were collected four weeks after the last inoculation.

Extracts of bacteria. Material was removed from the surface of bacteria by homogenization of $10-20 \mathrm{~g}$ wet wt in a blender (MSE, Atomix) at half speed for $5 \mathrm{~min}$ in $100 \mathrm{ml}$ volumes of $0.05 \mathrm{M}$-phosphate buffer, $\mathrm{pH} 7 \cdot 2$, containing $1 \mathrm{M}-\mathrm{NaCl}$ (Isaacson, 1977), followed by centrifugation at $20000 \mathrm{~g}$ at $4{ }^{\circ} \mathrm{C}$ for $60 \mathrm{~min}$. Proteins were differentially precipitated from the supernatant buffer by stepwise increases in ammonium sulphate concentration. After each stepwise increase, precipitate was removed by centrifugation $\left(20000 \mathrm{~g}\right.$ at $4{ }^{\circ} \mathrm{C}$ for $\left.10 \mathrm{~min}\right)$. Precipitates were then dialysed in $0.05 \mathrm{M}$-phosphate buffered isotonic saline (PBS), $\mathrm{pH} 7.0$.

Antigen $K 99$. K99 was prepared from $E$. coli K12 K99 by precipitation of an extract with $30 \%$ saturated ammonium sulphate and recovery of the precipitate by centrifugation and dialysis against PBS as described above.

Radioiodination of proteins. Partially purified proteins and antibodies to K99 were labelled with ${ }^{125}$ I by the chloramine T method (Hunter, 1978).

Polyacrylamide gel electrophoresis (SDS-PAGE). Slab gels were run with the discontinuous buffer system of Laemmli (1970). Polypeptides were located after staining with Coomassie brilliant blue and, where appropriate, by autoradiography. Molecular weights (corrected to three significant figures) were calculated by reference to the mobility of bovine serum albumin, ovalbumin, lactate dehydrogenase and myoglobin, relative to that of bromothymol blue, and were derived from the mean figures for five gels.

Immunoelectrophoresis (IE). The method of Morris \& Hussaini (1974) was used.

Immunodiffusion tests. The method of Ouchterlony \& Nilsson (1978) was used. Gels containing radiolabelled antigen were washed in ten changes of PBS followed by one change of distilled water over $5 \mathrm{~d}$. Where applicable, precipitin lines were cut out and boiled in an approximately equal volume of double strength sample buffer before layering onto gels for analysis by SDS-PAGE.

Column chromatography. Bacterial fractions $\left(500-700 \mu \mathrm{g}\right.$ protein $\left.\mathrm{ml}^{-1}\right)$ were applied in a sample volume of $1 \mathrm{ml}$ to a Sepharose 4B CL column (15 $\times 1 \mathrm{~cm}$; Pharmacia), equilibrated in PBS and eluted at a flow rate of $2 \cdot 0 \mathrm{ml} \mathrm{h}^{-1}$ at $4{ }^{\circ} \mathrm{C}$. Fractions were collected every $20 \mathrm{~min}$.

Chemical analysis. Protein concentrations were estimated spectrophotometrically by the method of Ehresmann et al. (1973). Carbohydrate concentrations were measured colorimetrically by the indole method for total carbohydrate (Ashwell, 1957), using sucrose as a reference.

Haemagglutination tests. The method of Burrows et al. (1976) was used. Tests were incubated at $4{ }^{\circ} \mathrm{C}$ for $2 \mathrm{~h}$ before reading. The test was modified (where applicable) for an assessment of mannose-sensitive haemagglutinins by excluding mannose from the buffer and by incubation of tests at $37^{\circ} \mathrm{C}$ for $2 \mathrm{~h}$. Bacterial extracts and suspensions were held at $100{ }^{\circ} \mathrm{C}$ for $30 \mathrm{~min}$ or treated with $0.5 \%(\mathrm{v} / \mathrm{v})$ formaldehyde at $37^{\circ} \mathrm{C}$ for $4 \mathrm{~h}$ prior to the test to assess temperature and chemical stability of the haemagglutinin. Resistance of haemagglutination to trypsin was examined as follows. $50 \mu \mathrm{l}$ trypsin solution $\left(10 \mathrm{mg} \mathrm{ml}^{-1}\right.$; Sigma, type III) was diluted in $450 \mu 1$ of haemagglutinin preparation containing $200 \mu \mathrm{g}$ of protein, and incubated at $37^{\circ} \mathrm{C}$ for $1 \mathrm{~h}$. To check the activity of the trypsin, samples were removed from the reaction mixture at intervals for analysis by SDS-PAGE. Trypsin was inactivated by incorporation of $2 \%(\mathrm{w} / \mathrm{v})$ bovine serum albumin in buffer used in haemagglutination tests.

Haemagglutination inhibition tests. A three volume test was used (total volume, $60 \mu \mathrm{l}$ ) in which preparations were diluted to 2 haemagglutinin units in $3 \%(\mathrm{w} / \mathrm{v})$ D-mannose. Antibody, serially diluted in a round-bottomed microtitre tray, and haemagglutinin were allowed to react for $30 \mathrm{~min}$ at $20^{\circ} \mathrm{C}$ before washed erythrocytes were added. Tests were incubated at $4{ }^{\circ} \mathrm{C}$ for $2 \mathrm{~h}$ before reading.

Brush border adhesion tests. Brush borders were prepared from 2 lengths of small intestine, taken $1 \mathrm{~m}$ above the ileo-caecal valve from calves $1-2 \mathrm{~d}$ old. The adhesion test was performed as described by Burrows et al. (1976). Inhibition of adhesion to brush borders was carried out by the addition of $10 \mu$ lof isolated adhesin $\left(200 \mu \mathrm{g} \mathrm{ml} \mathrm{m}^{-1}\right)$ to $100 \mu \mathrm{l}$ of PBS which contained approximately $10^{6}$ brush borders and $10^{8}$ bacteria. Preparations were then incubated at $37^{\circ} \mathrm{C}$ for $30 \mathrm{~min}$. Tests for adhesion of bacterial fractions to brush borders were carried out by the addition of $10 \mu \mathrm{l}$ of radiolabelled protein $\left(200 \mu \mathrm{g} \mathrm{ml}^{-1}\right)$ to $90 \mu \mathrm{l}$ of brush borders $\left[10^{6} \mathrm{ml}^{-1}\right.$ in PBS containing $1.5 \%$ $\left(\mathrm{w} / \mathrm{v}\right.$ ) bovine serum albumin], which were incubated at $37^{\circ} \mathrm{C}$ for $30 \mathrm{~min}$. Brush borders were then washed twice in buffer and counted in a PRIAS PGD Autogamma (Packard Instruments). A negative control consisted of nonadhesive brush borders (brush-borders lacking in K99 receptors) from a calf more than 1 week old. 
Production and isolation of $\mathrm{K}^{-9^{-}}$variants to E. coli B41. Ethidium bromide (BDH) was sterilized by filtration and added to Oxoid nutrient broth no. 2 at $100 \mu \mathrm{g} \mathrm{ml}^{-1}$. Broth cultures inoculated with $E$. coli $\mathrm{B} 41$ to give an initial concentration of 100 c.f.u. $\mathrm{ml}^{-1}$ were incubated statically at $37^{\circ} \mathrm{C}$ for $18 \mathrm{~h}$. After being subcultured in small numbers until the bacteria had passed through approximately 60 generations, broths were diluted and spread onto agar plates. Plates were incubated at $37^{\circ} \mathrm{C}$ for $18 \mathrm{~h}$ before colonies were tested for K99 production by slide agglutination, immunoradiometric assay, SDS-PAGE and IE. Alternatively, E. coli B41 was serially subcultured at $43{ }^{\circ} \mathrm{C}$ for $72 \mathrm{~h}$, diluted and spread onto agar plates which were incubated at $37^{\circ} \mathrm{C}$ for $18 \mathrm{~h}$ before colonies were tested for K99 production.

Selection and isolation of $\mathrm{K}^{9-} 9^{-}$variants of $E$. coli B4I. Escherichia coli B41 (109 organisms) were added to $4 \mathrm{ml}$ of rabbit antiserum raised against $E$. coli $\mathrm{K} 12 \mathrm{~K} 99$ and $1 \mathrm{ml}$ of rabbit serum which had been stored at $-70^{\circ} \mathrm{C}$ and served as a source of complement. The bacteria were incubated at $37^{\circ} \mathrm{C}$ for $24 \mathrm{~h}$. Serial dilutions were spread on plates and incubated at $37^{\circ} \mathrm{C}$ for $18 \mathrm{~h}$; colonies were examined for $\mathrm{K} 99$ production.

Immunoradiometric assay (IRA) for K99. Anti-K99 antibodies were purified by an immunosorbent method. A K99 preparation $\left(5 \mathrm{mg}\right.$ ) was further purified by adsorption to washed erythrocytes at $4{ }^{\circ} \mathrm{C}$ followed by three washes in PBS at $4{ }^{\circ} \mathrm{C}$ and by elution and separation from erythrocytes at $37^{\circ} \mathrm{C}$. The yield was $3 \mathrm{mg}$ and according to SDS-PAGE the preparation contained one polypeptide with mol. wt of 19000 . Purified K99 was attached to Sepharose 4B CL (Pharmacia) by the CN-Br method of Fuchs \& Sela (1978). The immunosorbent was mixed with $2 \mathrm{ml}$ of antiserum to $E$. coli $\mathrm{B} 41$ for $15 \mathrm{~min}$ at $20^{\circ} \mathrm{C}$ and washed five times in PBS. K 99 antibody was eluted by resuspension of the immunosorbent in $2 \mathrm{ml}$ of $0.1 \mathrm{M}$-glycine $/ \mathrm{HCl}$ buffer $\mathrm{pH} 2.0$ for $15 \mathrm{~min}$. The eluate was removed and the $\mathrm{pH}$ adjusted to $7 \cdot 4$ with $1 \mathrm{M}$-Tris/ $\mathrm{HCl}$ buffer.

Antibody to $\mathrm{K} 99(50 \mu \mathrm{g})$ was labelled with $0.5 \mathrm{mCi}(18.5 \mathrm{MBq})$ of ${ }^{125} \mathrm{I}$, centrifuged at $10000 \mathrm{~g}$ for $15 \mathrm{~min}$ and diluted to 10000 c.p.m. $(10 \mu \mathrm{l})^{-1}$ in IRA buffer $[1.5 \%(\mathrm{w} / \mathrm{v})$ bovine serum albumin, $10 \%(\mathrm{v} / \mathrm{v})$ foetal calf serum in PBS]. Suspensions $(100 \mu \mathrm{l})$ of approximately $10^{9}$ c.f.u. $\mathrm{ml}^{-1}$ were mixed with $10 \mu \mathrm{l}$ of ${ }^{125}$ I-labelled anti-K99 antibody, incubated at $4^{\circ} \mathrm{C}$ for $30 \mathrm{~min}, 37^{\circ} \mathrm{C}$ for $30 \mathrm{~min}$ and centrifuged at $10000 \mathrm{~g}$ for $2 \mathrm{~min}$. The supernatant was removed and the pellet washed twice by resuspension in IRA buffer and centrifugation at $10000 \mathrm{~g}$ for $2 \mathrm{~min}$. The radioactivity of both centrifuge tubes and pellets was counted.

Electron microscopy. Fractions of bacteria $\left(200 \mu \mathrm{g}\right.$ protein $\left.\mathrm{ml}^{-1}\right)$ in PBS were dropped onto Formvar/carboncoated grids. After $30 \mathrm{~s}$, excess fluid was removed with filter paper. The grids were then stained with $1 \%(\mathrm{w} / \mathrm{v})$ sodium phosphotungstate (pH 6.8).

Bacteria, on Formvar/carbon-coated grids, were fixed with $1 \%(w / v)$ aqueous osmium tetroxide, washed with distilled water and coated with gold/palladium at an angle of $45^{\circ}$ in an Edwards coating unit (Bradley, 1965). All specimens were examined in a Philips EM 300 at instrumental magnifications of 20000-55000 with an acceleration voltage of $80 \mathrm{kV}$.

\section{RESULTS}

\section{Isolation and characterization of a K99- variant of E. coli B4I}

Attempts to induce K99- variants of $E$. coli $\mathrm{B} 41$ by growth either in the presence of ethidium bromide or at high temperatures failed.

$96-97 \%$ of colonies of $E$. coli $\mathrm{B} 41$ which had been incubated with antiserum to $E$. coli $\mathrm{K} 12 \mathrm{~K} 99$ were entire, $2 \mathrm{~mm}$ in diameter and agglutinated by antisera to $E$. coli $\mathrm{K} 12 \mathrm{~K} 99$ and to $E$. coli $\mathrm{B} 41$ that were absorbed with organisms grown at $18^{\circ} \mathrm{C}$; this indicated the presence of $\mathrm{K} 99$. The remaining colonies were $4 \mathrm{~mm}$ in diameter, crenated and were agglutinated by absorbed antiserum to $E$. coli $\mathrm{B} 41$. They were not agglutinated by absorbed antiserum to $E$. coli $\mathrm{K} 12 \mathrm{~K} 99$. This pattern of agglutination remained constant after six subcultures at $37^{\circ} \mathrm{C}$ and indicated that the variants did not possess $\mathrm{K} 99$ but produced another antigen at $37^{\circ} \mathrm{C}$, but not at $18^{\circ} \mathrm{C}$.

One ${\mathrm{K} 99^{-}}^{-}$variant was chosen for further characterization. The IRA revealed that suspensions of the variant grown at $37^{\circ} \mathrm{C}$ containing $>10^{9}$ organisms $\mathrm{ml}^{-1}$ did not contain $\mathrm{K} 99$. The IRA was regularly capable of detecting $\mathrm{K} 99$ in suspensions of $10^{6} \mathrm{E}$. coli B41 ml-1 but did not react with $\mathrm{K} 99^{+} E$. coli grown at $18^{\circ} \mathrm{C}$.

SDS-PAGE of cell-free extracts, concentrated by precipitation in $36 \%$ saturated ammonium sulphate from the variant grown at $37^{\circ} \mathrm{C}$, revealed the absence of the $19000 \mathrm{~mol}$. wt polypeptide subunit of K99. The $34000 \mathrm{~mol}$. wt polypeptide subunit of the anionic adhesin was of comparable intensity to that of the parent strain (Fig. 1).

IE performed with cell-free extracts from the $\mathrm{K} 99^{-}$variant and absorbed antiserum to $E$. coli B41 produced one anionic precipitin line. The cationic line produced in this test by cell-free extracts from $\mathrm{K} 99^{+} E$. coli B41 was absent. 


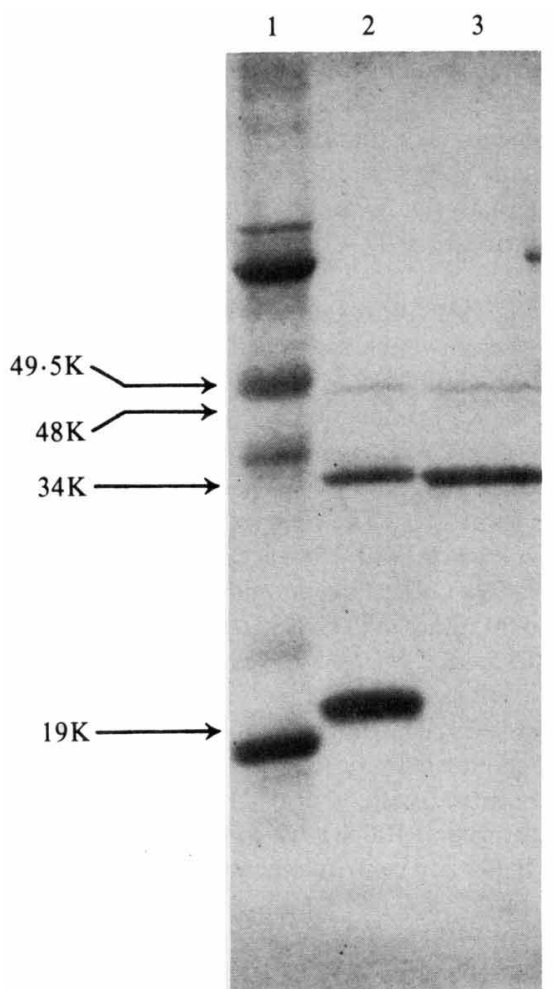

Fig. 1

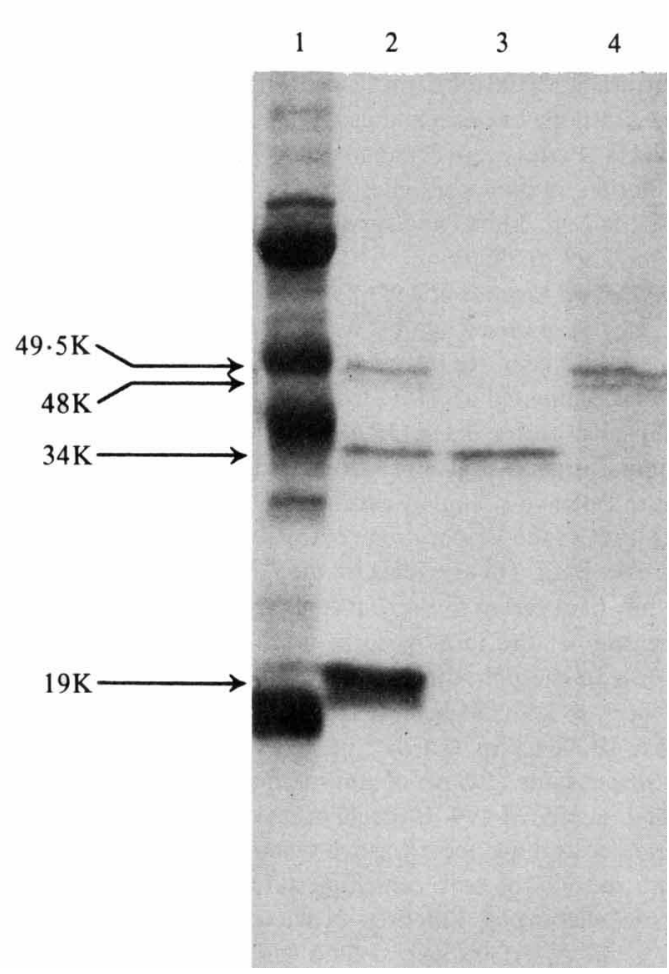

Fig. 2

Fig. 1. SDS-PAGE of cell extracts from $E$. coli B41 (lane 2) and the K99- E. coli (lane 3). Lane 1 contains the molecular weight standards. This result has been reproduced five times.

Fig. 2. SDS-PAGE of a cell extract from $E$. coli B41 (lane 2), $30 \%$ ammonium sulphate fraction of a cell extract from the K99- E. coli B41 (lane 3) and a subsequent $45 \%$ ammonium sulphate fraction (lane 4). Lane 1 contains the molecular weight standards. This result has been reproduced four times.

The variant when grown at $37^{\circ} \mathrm{C}$ adhered to brush borders $(>10-12$ bacteria per brush border). By contrast, the variant when grown at $18^{\circ} \mathrm{C}$ did not adhere to brush borders but did adhere to other refractile material in brush border preparations. The wild-type $E$. coli B41 reacted in brush border tests in the same way.

\section{Partial purification and characterization of the anionic adhesin}

A cell extract from the $\mathrm{K}^{99^{-}}$variant of $E$. coli $\mathrm{B} 41$ made $30 \%$ saturated with ammonium sulphate developed a precipitate which was soluble in PBS and contained approximately $50 \%$ protein and $50 \%$ carbohydrate. SDS-PAGE revealed a single polypeptide of mol. wt 34000 (Fig. 2). The carbohydrate component was reduced to $4 \%$ without loss of haemagglutinating activity by four serial precipitations at $\mathrm{pH} 4.2$ (Stirm et al., 1967). This material produced a single anionic line when tested by IE against $E$. coli B41 antiserum. Antiserum to this preparation agglutinated $\mathrm{K} 99^{+} E$. coli B41 organisms grown at either 18 or $37^{\circ} \mathrm{C}$. When absorbed with $\mathrm{K} 99^{-}$organisms grown at $18^{\circ} \mathrm{C}$, this antiserum agglutinated only $\mathrm{K} 99^{-}$E. coli grown at $37^{\circ} \mathrm{C}$. These findings suggested that the partially purified polypeptide was contaminated with small amounts of O-antigen.

A solution of the anionic adhesin, which contained $30 \mu \mathrm{g}$ protein $\mathrm{ml}^{-1}$, caused agglutination of sheep and horse erythrocytes to titres of $1 / 256$ and $1 / 64$, respectively. Treatment with trypsin or formaldehyde did not affect the haemagglutination titre but the titre was reduced to less than 
$20 \%$ by prior treatment of the adhesin at $100{ }^{\circ} \mathrm{C}$ for $30 \mathrm{~min}$. In contrast, the $\mathrm{K} 99$ haemagglutination titre was reduced by all three treatments.

Anionic adhesin inhibited adhesion of the $\mathrm{K}^{-1} 9^{-} E$. coli B41 to brush borders by more than $90 \%$, but did not inhibit adhesion of $\mathrm{K}^{+} 9^{+}$E. coli $\mathrm{B} 41$ or $E$. coli $\mathrm{K} 12 \mathrm{~K} 99$ to brush borders. Radiolabelled anionic adhesin reacted with adhesive brush borders with a binding ratio (defined as count/background count) of three, but did not react with non-adhesive brush borders. In contrast, radiolabelled $\mathrm{K} 99$ reacted with adhesive brush borders with a binding ratio of less than two, which was not considered significant. Unlabelled K99 was unable to prevent the adhesion of $E$. coli $\mathrm{B} 41, \mathrm{~K}^{-} 9^{-} E$. coli B41 or $E$. coli $\mathrm{K} 12 \mathrm{~K} 99$ to brush borders.

Anionic adhesin eluted from a Sepharose 4B CL column in the void volume, which indicated that the $34000 \mathrm{~mol}$. wt subunits were assembled into structures of mol. wt greater than $20 \times 10^{6}$. Electron micrographs of negatively stained preparations of anionic adhesin revealed both long parallel-sided processes, approximately $3 \mathrm{~nm}$ in diameter (Fig. $3 b$ ) and structures with irregular morphology which predominated (Fig. $3 a$ ).

\section{Partial purification and characterization of a non-K99 non-anionic adhesin MRE haemagglutinin}

The extract of the K99- variant of $E$. coli $\mathrm{B} 41$ from which the anionic adhesin had been removed by $30 \%$ saturated ammonium sulphate was made $45 \%$ saturated with respect to ammonium sulphate and stirred at $4{ }^{\circ} \mathrm{C}$ for $2 \mathrm{~h}$. The precipitate was redissolved and dialysed in PBS and, following centrifugation $(20000 \mathrm{~g}, 10 \mathrm{~min})$, contained $95 \%$ protein and $5 \%$ carbohydrate. SDS-PAGE revealed two closely spaced polypeptides of 49500 and $48000 \mathrm{~mol}$. wt (Fig. 2). A solution of $35 \mu \mathrm{g}$ protein $\mathrm{ml}^{-1}$ caused agglutination of sheep erythrocytes to a titre of $1 / 1024$, but did not agglutinate horse or guinea pig erythrocytes. Sheep haemagglutinin eluted within $30 \mathrm{~min}$ at $37^{\circ} \mathrm{C}$. This haemagglutinin was resistant to prior treatment by heating to $100^{\circ} \mathrm{C}$ for $30 \mathrm{~min}$ and to the action of formaldehyde and trypsin. SDS-PAGE of trypsin-treated haemagglutinin revealed that the trypsin autodigested after $1 \mathrm{~h}$, whilst the strength of the stained 49500 and $48000 \mathrm{~mol}$. wt polypeptides remained constant as did the sheep haemagglutination titre. Partially purified haemagglutinin was unable to cause haemagglutination of sheep or horse erythrocytes at $37^{\circ} \mathrm{C}$ in the absence of D-mannose.

Antiserum to this preparation inhibited haemagglutination at a titre of $1 / 64$, whereas the same antiserum did not inhibit haemagglutination by the anionic adhesin. Antiserum to the anionic adhesin inhibited agglutination of sheep erythrocytes caused by both the $30 \%$ and $45 \%$ saturated ammonium sulphate fractions at titres of $1 / 128$ and $1 / 128$, respectively. However, normal rabbit serum was equally inhibitory to haemagglutination by the $45 \%$ ammonium sulphate fraction. Thus the interaction between antiserum to anionic adhesion and the $45 \%$ ammonium sulphate fraction was probably not due to specific antibody. This was supported by the fact that antiserum to the anionic adhesin gave no line of precipitin in immunodiffusion tests with the $45 \%$ saturated ammonium sulphate fraction.

Since absorption of $\mathrm{OK}$-antiserum with bacteria grown at $18{ }^{\circ} \mathrm{C}$ did not affect the production of an anionic line in IE, the $45 \%$ ammonium sulphate fraction is presumably antigenically different from the anionic adhesin.

SDS-PAGE of extracts of K99- E. coli B41 grown at $18^{\circ} \mathrm{C}$ revealed the 49500 and $48000 \mathrm{~mol}$. wt polypeptides, but not the $34000 \mathrm{~mol}$. wt anionic adhesin. The mixture containing 49500 and $48000 \mathrm{~mol}$. wt polypeptides was unable to prevent adhesion of the $\mathrm{K}^{2} 9^{-}$E. coli $\mathrm{B} 41, E$. coli $\mathrm{B} 41$ and $E$. coli $\mathrm{K} 12 \mathrm{~K} 99$ to brush borders. Likewise, neither $\mathrm{K} 99^{-}$E. coli $\mathrm{B} 41$ grown at $18^{\circ} \mathrm{C}$ nor radiolabelled 49500 and $48000 \mathrm{~mol}$. wt polypeptides adhered to brush borders.

In preparations of the $45 \%$ ammonium sulphate fraction applied to a Sepharose 4B column, both haemagglutinin activity and the 49500 and 48000 mol. wt polypeptides eluted together within the void volume. This indicated that either or both of the 49500 and $48000 \mathrm{~mol}$. wt polypeptides could be aggregated in the haemagglutinin having a mol. wt of greater than $20 \times$ $10^{6}$. Electron micrographs of negatively stained haemagglutinin revealed a mass of long parallelsided processes of approximately $10 \mathrm{~nm}$ in diameter (Fig. $3 c$ ), which tended to aggregate in a regular fashion. 

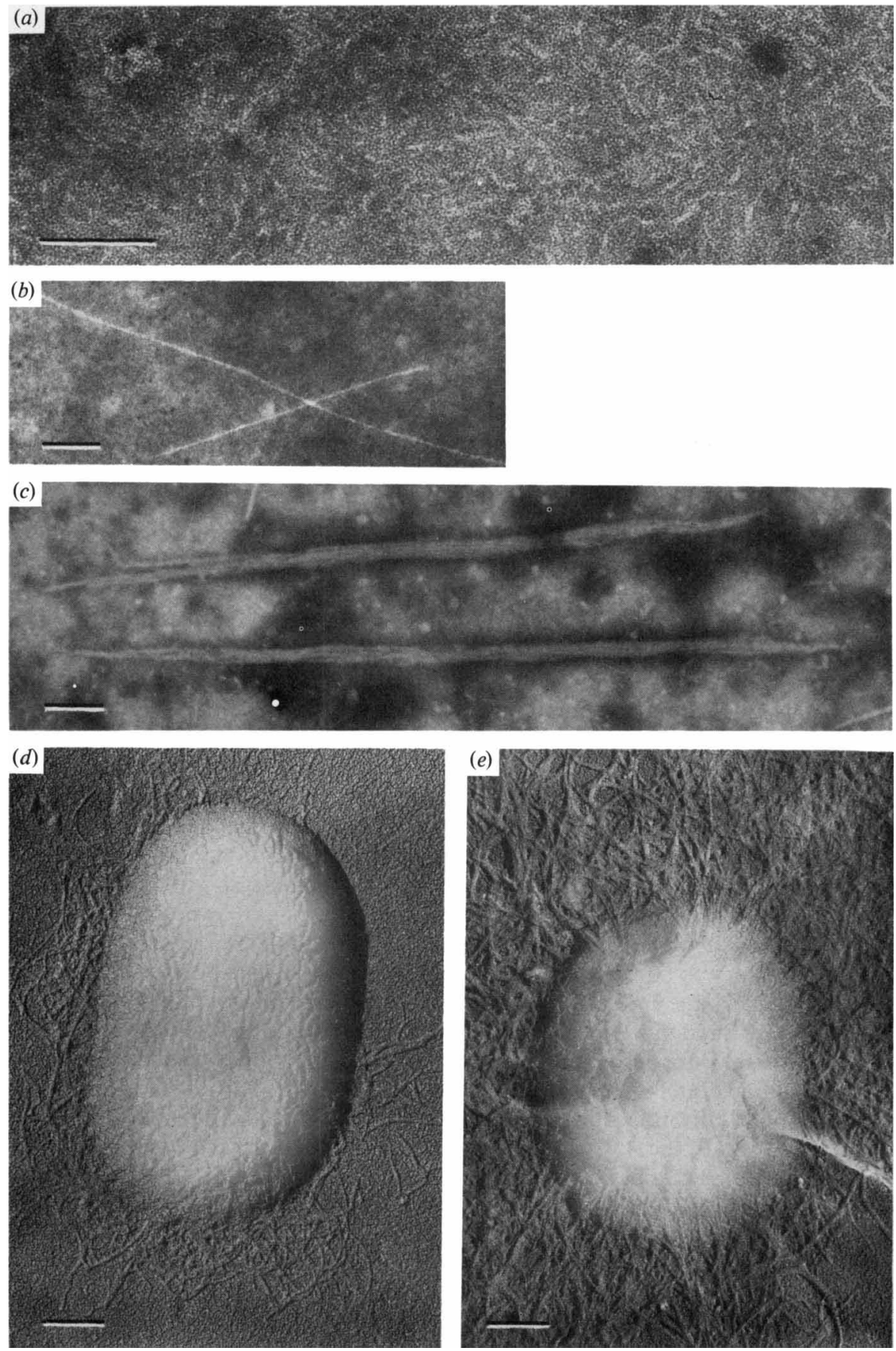

Fig. 3. Electron micrographs of negatively stained anionic adhesin found in $30 \%$ saturated ammonium sulphate precipitates of cell-free extracts from a K99- E. coli B41 showing $(a)$ irregular structures and $(b)$ fimbriae-like structures; $(c)$ heat resistant fimbrial haemagglutinin found in $45 \%$ saturated ammonium sulphate precipitates, see Methods; $(d, e)$ electron micrographs of shadow cast K99- $E$. coli B41 and $E$. coli $\mathrm{K} 12$ grown at $18^{\circ} \mathrm{C}$. This result has been reproduced twice. The bar markers represent $100 \mathrm{~nm}(a, b$, c) and $200 \mathrm{~nm}(d, e)$. 
Assessment of heat resistant haemagglutinin production by different $E$. coli

All K $99^{+}$and $\mathrm{K} 12$ E. coli produced a mannose-and heat-resistant sheep haemagglutinin when grown at 18 and $37^{\circ} \mathrm{C}$. The 987p (M2225) and K88 (W1) strains did not.

Electron micrographs of E. coli B41, K99- B41, K12 K99, K 12 and K 12 C600 grown at $18^{\circ} \mathrm{C}$ showed the presence of fimbriae (Fig. 3), whereas electron micrographs of W1 and M2225 cultured at $18^{\circ} \mathrm{C}$ did not reveal fimbriae. SDS-PAGE of surface proteins from B41, K12, $\mathrm{K} 99$, $\mathrm{K} 12$, S13 and B117 revealed a couplet of polypeptides with molecular weights identical to those in the haemagglutinin preparation.

The heat- and mannose-resistant haemagglutinins of $E$. coli $\mathrm{K} 12$ and $\mathrm{K} 99^{-} E$. coli $\mathrm{B} 41$ were antigenically similar, since antiserum to the haemagglutinin preparation caused strong slide agglutination of $\mathrm{K}^{2} 9^{-} E$. coli $\mathrm{B} 41$ and $E$. coli K12. Absorption of the antiserum with either $E$. coli $\mathrm{K} 12$ or $E$. coli B41 removed the ability to slide agglutinate $\mathrm{K} 99^{-} E$. coli $\mathrm{B} 41$ and the ability to form a precipitin line in immunodiffusion tests with partially purified haemagglutinin. SDSPAGE analyses by autoradiography of the precipitin line between radiolabelled haemagglutinin and wells containing antiserum to whole live $E$. coli B41 revealed the 49500 and 48000 mol. wt polypeptides.

Escherichia coli strains $\mathrm{K} 12$ and $\mathrm{K} 99^{-} \mathrm{B} 41$ did not produce a heat- and mannose-resistant sheep haemagglutinin when grown on $5 \%(\mathrm{v} / \mathrm{v})$ bovine blood agar at $18^{\circ} \mathrm{C}$ or $37^{\circ} \mathrm{C}$. The $\mathrm{K} 99^{-}$ $E$. coli B41, however, did produce a heat-sensitive, mannose-resistant sheep and horse erythrocyte haemagglutinin on this medium when grown at $37^{\circ} \mathrm{C}$. However, electron micrographs revealed that less than $10 \%$ of bacteria produced fimbriae similar in appearance to those produced at $18^{\circ} \mathrm{C}$ on TGX medium. SDS-PAGE analysis of the $45 \%$ saturated ammonium sulphate fraction from the $\mathrm{K}^{-} 9^{-}$E. coli $\mathrm{B} 41$ grown on $5 \%$ bovine blood agar at $37^{\circ} \mathrm{C}$ for $18 \mathrm{~h}$ revealed traces of 34000,48000 and 49500 mol. wt polypeptides. Haemagglutination tests with this fraction showed the presence of both a heat-sensitive horse haemagglutinin and a heat-resistant sheep haemagglutinin. Thus, the fractionation procedure presumably concentrated the heat-resistant haemagglutinin, which was otherwise undetectable.

\section{DISCUSSION}

Chanter (1982) purified the anionic adhesin by IE, but this yielded a preparation contaminated by agar and antibody and was suitable only for subunit mol. wt determinations. Other purification procedures consistently resulted in preparations contaminated with $\mathrm{K} 99$. The production of a $\mathrm{K}^{-} 9^{-}$variant of $E$. coli $\mathrm{B} 41$ seemed critical to the characterization of the anionic adhesin both in vitro and in vivo. $E$. coli $\mathrm{B} 41$ is a complement-sensitive strain (N. Chanter \& $\mathrm{P}$. W. Jones, unpublished results) and it was thought that killing might be enhanced by the presence of specific antibody thus facilitating isolation of $\mathrm{K} 99^{-}$variants. This was confirmed when $2-4 \%$ of $E$. coli $\mathrm{B} 41$ incubated in antiserum to $E$. coli $\mathrm{K} 12 \mathrm{~K} 99$ lost the ability to produce K99, but retained the ability to produce the anionic adhesin. Escherichia coli K12 K99 produced K99 but not the anionic adhesin. Anionic adhesin could be purified from the variant to give a $98 \%$ pure preparation composed of the $34000 \mathrm{~mol}$. wt polypeptide. This preparation behaved in IE, inhibition of brush border adhesion tests, brush border adhesion tests and haemagglutination tests as previously described by Morris et al. (1980). Polymerization of the $34000 \mathrm{~mol}$. wt subunits, resulted in an aggregate with mol. wt in excess of $20 \times 10^{6}$. Attempts to visualize fimbriae in preparations of the aggregated anionic adhesin were unsatisfactory. However, occasionally fimbriae-like structures were seen which were finer than those seen in K99 preparations and in preparations containing the heat-resistant sheep haemagglutinin. The anionic adhesin may be a fragile fimbrial structure which readily breaks down into the irregular structures which predominated in negatively stained preparations. It seems, however, that a fimbrial structure is not required for haemagglutination and brush border adhesion.

Awad-Masalmeh et al. (1982) isolated a non-fimbrial mannose-resistant haemagglutinin from a $\mathrm{K} 88^{-} \mathrm{K} 99^{-} 987^{-}$enterotoxigenic $E$. coli which assisted intestinal colonization by attachment to intestinal cells. This adhesin was antigenic and was not produced at $18{ }^{\circ} \mathrm{C}$. These properties 
are similar to those of the anionic adhesin from $E$. coli B41. The porcine adhesin, however, had a subunit molecular weight described as only slightly greater than that of K99. The pattern of resistance of the anionic adhesin to the action of trypsin and formaldehyde was quite different from that of K99. The sensitivity of K99 to these treatments may indicate a generally labile nature which might explain its apparent inactivity, following purification, in brush border adhesion tests when compared with the anionic adhesin (Morris et al., 1980). The anionic adhesin and the heat stable haemagglutinin were unable, however, to prevent the adhesion of $E$. coli $\mathrm{B} 41$ and $E$. coli $\mathrm{K} 12 \mathrm{~K} 99$ to brush borders. Under these conditions, adhesion of whole bacteria caused by anionic adhesin or heat-stable haemagglutinin would presumably be blocked, so that the observed adhesion of bacteria must have been caused by bacteria-bound K99. K99 preparations contained fimbriae (unpublished result). The stability of the fimbrial structure of K99, therefore, did not ensure biological activity.

To the author's knowledge, the presence of haemagglutinating fimbriae on $E$. coli, resistant to $100{ }^{\circ} \mathrm{C}$ for $30 \mathrm{~min}$ and composed of two polypeptide subunits of different size has not been described previously. These structures were unlikely to be flagella since they had little or no amplitude. In addition, flagella of $E$. coli are $13 \mathrm{~nm}$ in diameter (De Pamphilis \& Adler, 1971) and those of the Enterobacteriaceae are generally composed of a single polypeptide subunit of mol. wt 40000 (Iino, 1969). Heat-resistant haemagglutinin was purified from bacteria grown on solid media and electron microscopy of bacteria grown under these conditions showed an absence of flagellate cells. Eshdat et al. (1981) indicated that type 1 fimbriae could not be disaggregated by denaturing conditions commonly employed in SDS-PAGE so that the possibility that the long parallel-sided structures seen in preparations of heat-resistant haemagglutinin were type 1 fimbriae could not be excluded. However, partially purified haemagglutinin did not contain any mannose-sensitive haemagglutinating activity at $37^{\circ} \mathrm{C}$. Also the heat-resistant sheep haemagglutinin does not seem to be related to the major outer membrane proteins of $E$. coli (Hofstra \& Dankert, 1979; Paakkanen et al., 1979).

The heat resistance of this haemagglutinin is exceptional for a protein. It is possible that its structure is stabilized by cystine disulphide bridges. The exclusion of 2-mercaptoethanol from the sample buffer for SDS-PAGE did not reduce the number of bands, an effect observed with other fimbriae which contain intrasubunit cystine disulphide bridges (Isaacson, 1981; Chanter, 1982). However, inter-polypeptide disulphide bridges are less likely when the distance between cysteine residues in the primary structure of polypeptides is small (Martin, 1964).

The subunit molecular weights of the heat-resistant sheep haemagglutinin are unusually large compared to nearly all of the previously described fimbriae. However, Lugtenberg et al. (1976) in a study of the outer membrane proteins of E. coli K 12 identified a $50000 \mathrm{~mol}$. wt band in SDSPAGE gels as pilin subunits of fimbriae found on some, but not all, E. coli K12 strains.

The heat-resistant sheep haemagglutinin did not seem to be involved in adherence to calf intestinal brush borders. It is possible that this haemagglutinin binds a receptor in the mucosal layers that would have been removed during brush border preparation. Alternatively, this component may possess another as yet unidentified role in virulence.

I would like to thank Dr J. M. Rutter, Dr D. J. Garwes and Mr R. Sellwood for advice and encouragement and also Dr D. J. Garwes for radioiodinations and $\mathrm{Mr} \mathrm{H}$. Anger for assistance with electron microscopy.

\section{REFERENCES}

AsHWELL, G. (1957). Colorimetric analysis of sugars. Methods in Enzymology 3, 73-105.

Awad-Masalmeh, M., Moon, H. W., Runnels, P. L. \& SCHNEIDER, R. A. (1982). Pilus production, haemagglutination, and adhesion by porcine strains of enterotoxigenic Escherichia coli lacking K88, K99, and 987P antigens. Infection and Immunity 35, 305-313.

Bradley, D. E. (1965). Replica and shadowing techniques. In Techniques for Electron Microscopy, 2nd edn, pp. 96-153. Edited by D. H. Kay. Oxford: Blackwell Scientific Publications.
Burrows, M. R., Sellwood, R. \& Gibbons, R. A. (1976). Haemagglutinating and adhesive properties associated with K99 antigen of bovine strains of Escherichia coli. Journal of General Microbiology 96, 269-275.

Chanter, N. (1982). Structural and functional differences of the anionic and cationic antigens in K99 extracts of Escherichia coli B41. Journal of General Microbiology 128, 1585-1589.

De Pamphilis, M. L. \& Adler, J. (1971). Fine structure and isolation of the hook-basal body 
complex of flagella from Escherichia coli and Bacillus subtilis. Journal of Bacteriology 105, 384-395.

Ehresmann, B., Imbault, P. \& Weil, J. H. (1973). Spectrophotometric determination of protein concentration of cell extracts containing tRNAs and rRNAs. Analytical Biochemistry 54, 454-463.

Eshdat, Y., Silverblatt, F. J. \& Sharon, N. (1981). Dissociation and reassembly of Escherichia coli type 1 pili. Journal of Bacteriology 148, 308-314.

FuCHS, S. \& SELA, M. (1978). Immunoadsorbents. In Handbook of Experimental Immunology, 3rd edn, pp. 10.1-10.6. Edited by D. M. Weir. Oxford : Blackwell Scientific Publications.

Hofstra, H. \& DANKeRr, J. (1979). Antigenic cross reactivity of major outer membrane proteins in Enterobacteriaceae species. Journal of General Microbiology 111, 293-302.

HUNTER, W. M. (1978). Radioimmunoassay. In Handbook of Experimental Immunology, 3rd edn, pp. 14.114.50. Edited by D. M. Weir. Oxford: Blackwell Scientific Publications.

IINO, T. (1969). Genetics and chemistry of bacterial flagella. Bacteriological Reviews 33, 454-475.

ISAACSON, R. E. (1977). K99 surface antigen of Escherichia coli: purification and partial characterisation. Infection and Immunity 15, 272-279.

ISAACSON, R. E. (1981). Pili of enterotoxigenic Escherichia coli. In Proceedings of the Third International Symposium on Neonatal Diarrhoea, pp. 213-236. Edited by S. D. Acres, A. J. Forman \& H. Fast. Saskatoon, Canada: VIDO.

LAEMMLI, U. K. (1970). Cleavage of structural proteins during the assembly of the head of bacteriophage T4. Nature, London 227, 681-685.

Lugtenberg, B., Peters, R., Bernheimer, H. \& BERENDSEN, W. (1976). Influence of cultural conditions and mutations on the composition of the outer membrane proteins of Escherichia coli. Molecular and General Genetics 147, 251-262.
MARTIN, R. B. (1964). Protein conformation. In Introduction to Biophysical Chemistry, pp. 225-239. Edited by R. B. Martin. New York: McGraw-Hill.

Moon, H. W., NAGY, B., IsAacson, R. E. \& ØrSKov, I. (1977). Occurrence of K99 antigen on Escherichia coli isolated from pigs and colonisation of pig ileum by $\mathrm{K} 99^{+}$enterotoxigenic $E$. coli from calves and pigs. Infection and Immunity 15, 614-685.

Morris, J. A. \& HussainI, S. N. (1974). Characterisation of the antibodies detected by the microscopic agglutination test for bovine leptospirosis. Journal of Hygiene 73, 425-432.

Morris, J. A., Thorns, C. J. \& SoJKA, W. J. (1980). Evidence for two adhesive antigens on the K99 reference strain Escherichia coli B41. Journal of General Microbiology 118, 107-113.

OUCHTERLONY, O. \& Nilsson, L.-A. (1978). Immunodiffusion and immunoelectrophoresis. In Handbook of Experimental Immunology, 3rd edn, pp. 19.1-19.43. Edited by D. M. Weir. Oxford : Blackwell Scientific Publications.

PaAkKanen, J., Gotschlich, E. C. \& Mäbelä, P. H. (1979). Protein $\mathrm{K}$ : a new major outer membrane protein found in encapsulated Escherichia coli. Journal of Bacteriology 139, 835-841.

SMITH, H. Williams \& LiNGOOD, M. A. (1972). Further observations on Escherichia coli enterotoxins with particular regard to those produced by atypical piglet strains and by calf and lamb strains: the transmissible nature of these enterotoxins and of a $\mathrm{K}$ antigen possessed by calf and lamb strains. Journal of Medical Microbiology 5, 243-250.

SoJKA, W. J. (1965). Escherichia coli in domestic animals and poultry. Review Series, Commonwealth Bureau of Animal Health, no. 7.

STIRM, S., ØrSKov, F., ØrSKov, I. \& MANSA, B. (1967). Episome carried surface antigen K88 of Escherichia coli. II. Isolation and chemical analysis. Journal of Bacteriology 93, 731-739. 